\title{
Parenting as Character Education Model
}

\author{
Eko Sumargo, Soedjarwo, Erny Roesminingsih \\ Department of Educational Management \\ Universitas Negeri Surabaya \\ Surabaya, Indonesia \\ ekosumargosukamade@gmail.com
}

\begin{abstract}
This research aims to develop a model parenting conceptual as a framework partnership relationship between school with the parents of students in order to develop and apply a character education program at an elementary school. This study was conducted in two stages at the preparatory stage and the implementation. The preparation stage was intended to produce a model parenting using the 4-d development concept. The tested model aims to measure the extent of the level feasibility model parenting that was produced. Parenting model produced consisting of five measures that are building partnerships, arrange a program, practice the program, character surveillance program, and evaluation. Based on the analysis of the data shows that the percentage feasibility model parenting produce as much as good catagoration. This indicates that parenting model can produce framework conceptual to carry out character education.
\end{abstract}

Keywords-parenting model; character education; character development

\section{INTRODUCTION}

Actually, education is preparing students to be able to spend our future well. According to Trailing and Fadel, character education is still very relevant to be implemented in the 21. The Indonesian government firmly introduced the character education strengthening to be implemented in throughout the entire country. Education leads to develop the character of a whole, integrated, and balanced improve the quality of processes and results education. Writer Found character as fundamental values of personal someone who built, formed either because the impact of the descent and environmental influences, who be a characterizes from others, and embodied in attitude and his behavior in his life. Character is ways of thinking and behaving which is typical of individuals to live and collaborate, both in small family groups, the community, states and nations [1].

Character education is a conscious and earnest from a teacher to teach the value to their students. Being Lickona said character education as earnest efforts to help somebody to understand, care and acting with the ethical core values [2]. Lickona added character education as an effort to designed deliberately to fix the character of the students. Character education is any positive thing who doing by teachers and it have a large influence for students [3].

The Indonesian Government has establishing the strengthening of character education through The Ministry of
Education And Culture to realize the message constitution. The Minister said strengthening character education is schoolbased education program to strengthen character of students through sports harmonisation of conduct and spiritual. There are five main character stressed in establishing character education are religious, nationalist, independent, mutual, and integrity.

Character education is very important to be implemented. Character education in Indonesia is perceived need development considering because of the increases in fighting between students, extortion / (bullying), violence the tendency of senior yunior, and phenomena fights supporters football and other forms of mischief teenage. especially in large cities. Even the splashy is education of a students through an honesty canteen in schools has failed. Many efforts an honesty canteen insolvent because they have not been the rise in children. being honest. Meanwhile information from the national narcotics agency said there are 3,6 million drug addicts in Indonesia.

The character in the community is also very worrying. The discipline and orderly traffic the community has already been very low. Level of public awareness to be cultivating, lined up the clean, life habit, and desire appreciate environment are still provided at below. As a nation, to some extent we are still worried that the had got the inferiority complex national, prove to be the case still like to and devoured without the selection of all product and familiar culture. The worst thing, the media also forget its role to continue to educate the people and motivate love the nation culture. Also culture honest officials are very low. Corruption, collusion and nepotism be a culture that's difficult to remove. That's why we needs education character in all levels of education [4].

The education character of a child obtained from three sources education who known as the term three centers education. According to Indonesian Education Law, members of the three centers education are family (informal education), school (formal education) and community (non-formal education). Each element in three centers education has the role and the particular in support of the success of a child in the future. Third of education should be able to get full education relevant to a students.

The role of family in educating children is very important. In family environment, a child get education first. The character of a child formed in when he was in the first phase to grow with their family. The character of a child are imitate 
characters around his family. As the saying goes fruit fall is not far from the tree. If the custody of the children in their family good so they would grow be a good boy .But if the child custody in family not good so they will grow into bad boy [5].

As time goes on, a child need education broader and intensity regular outside the scope of the family. The ages of six to seven years, a child entering the formal education that's entering the level of primary school. School is formal institution that is deliberately created to provide education broader and fuller compared to education provided by parents. Schools furnished with various instruments who are expected to shape the process of quality so that every child get good quality education. At school children will many studies science, skills, and sociable. There are four types functions of the school that provide services to students to be able to acquire knowledge or academic skills required in their life. Develop skills needed in life, living together and collaborates with others, so that students can put himself [6].

In the primary school, the time between children with parents being reduced. Many children spend time with friends and teachers at their school. Although they has spent time in school to study does not mean that parents will no longer have an obligation to educate their children. As good as any the quality of education in schools will not be able to shift the role of parents in educating their children. Parents have to work with the schools in educating their children without removing the task of each other.

Ideally parents should understand how to educate her own son. Lickona said the parents is the main indicator of success at the school. Even the involvement of parents to can help schools directly in educating the child character more effective than in the background education and the economy of the parents may. According to a survey conducted by researchers, $80 \%$ of parents admitted educating children on the basis of what is done by their parents had in educating himself. It means that parents only repeat what have they got in the past to be applied today. If they get good in the past so they will give their children good education also, but if they get bad education so it will make bad education for their children. In a hadiths messenger of god said "Teach your children accordance with his day, because they live in his day is not in your days. Indeed they were created of her time, while you were made to the days of you". Still according to the survey researchers, $70 \%$ parents have not been implemented how to teach children (parenting) in the schools or voluntary attend an event how to teach children in other place.

There are several definition of the experts related parenting. Parenting interprets as a process honing the skills educating children based on a good rules and noble. Foster pattern is the way educating children one who lays stress on certain rules based on affection of parents. Parenting is embodiment a sense of the responsibility of the parents to a child in the form of best education. Parenting is the effort to parents who actualized on social structuring the environment, cultural environment, psychological mood and behavior that be showed during the occurrence of a meeting with the kids [7].
Expected outcomes from parenting program is a partnership between the school and parents on strengthening the character education. School understand the task and the school to educating children when they are in school. Parents also understand portions and its role in educating. at home.

So far of associated research parenting is widely practiced. Produces the foster parents very influential dominant on the lives of children. A pattern that has a more positive autoritatif of education and child psychology. Roman who conclusions of the positive and fulfilling basic needs of psychology influence on a child goal. Leckli, L \& Kaloti produce the conclusion that cooperation between the parents and teachers can improve academic performance students. Not only that the attitudes and students participation will increase. But the research with the development model parenting character education at the level of primary schools have not done [8].

A public elementary school in in Perak Jombang called Glagahan 2 elementary school related problems parent participation in his character education. According to interviews with the teachers of Glagahan 2 Perak elementary school, parents of the students from this school have low enrollment in supporting their children education. Even to simply open study results report of their children have been so reluctant to do it. Low enrollment in these, affect the student in this school tend to be less good. According to interviews with some students researchers found that they have less religious character demonstrated by the low their ability to recite prayers and reading holy Qur'an. Character nationalism is still low. This is shown students by often scoffed each other because they differ in terms of the support certain football clubs. Integrity characters also still low. This can be observed of responsibility daily pickets class remain low. That's why researchers want to do research in Glagahan 2 Perak Jombang elementary school with a title development model parenting to strengthen character education in Glagahan 2 Perak Jombang elementary school. It is expected parenting program, participation parents to education children can rise. And with the participation of parents can make quality character students in this school rose.

\section{METHOD}

A kind of research approach used in this research was the qualitative study. While the research is trying to do research and development $(\mathrm{RnD})$. The development of which research methods used is the method research and development belonging to Sugiyono. Acoording to Berkowitz research and development is that research was intended to produce certain products and for measuring how effective the products were. Methods used in this research is descriptive research. Research methods that were to analyze and describe the results of the study but not used in order to make inferences broader. Object research development in this is model of parenting to strengthen character education in primary school [9].

There are ten steps in its research and development. But due to time limitations and research will be done only up to a pilot phase to six. 


\section{RESULTS AND DISCUSSION}

\section{A. Product of Parenting Model}

The product model designed adapted to the Lickona. The parenting model is shown as picture below.

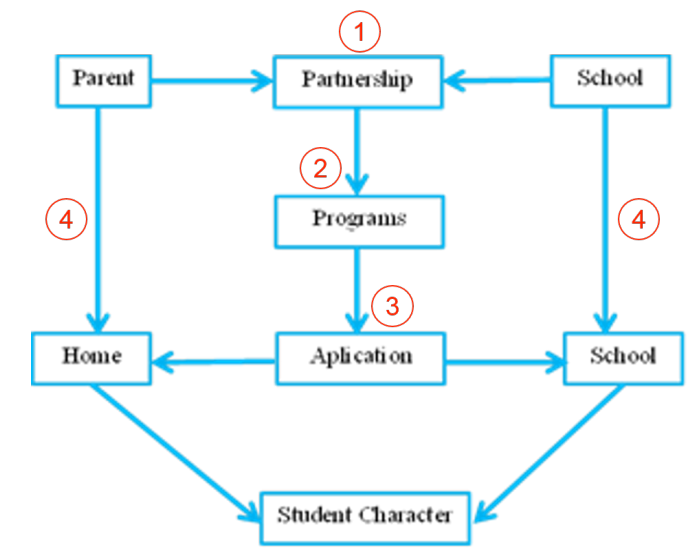

Fig. 1. Parenting model

A picture above is the parenting design. On the model, it was recorded five steps of work to carry out character education at school and at home [10]. Work step by among other partner schools with the parents of students, together to make preparation of the character program, the application of character program, supervision character program, and evaluation character program [11].

Forming a partnership between school and parents are the communication both sides to find an understanding that forming students characterless is very important. This task is the duty among school and parents, is not the job of one side [12]. Forms of activity this partnership can be done by means of regular meeting which was attended by all parents of students, monthly meetings which is attended by parents in every class and consultation by the social media or direct meetings. The implementation of this partnership is $90 \%$ [13].

Partnership started with school invite parents to attend a school meeting. School prepared materials that proposed during the meeting such as A guidebook parenting, procedures the use of parenting book, and teachers who posted to given the lectures meeting.

The preparation of the program characters to be applied in school and at home is a result of this partnership. School And home had same opertunity to make a character program. But in the early program, school prefer to make a program for character education. Character program must contain education, motivation, exemples, and habituation. Education make student knowing the good. Motivation and example make student feeling the good. And habituation make student doing the good. All the program must write in a book. The book was called parenting book. The book would teach some of student parent how to educate his son or dougther at home. The program would not work properly without parent partisipation.

Character education program could be renew every a month. Parent could show her/his idea about character education program. The idea could be brougt in parent and school meeting. The implementation of this character programs established as $85 \%$ [14].

The application of program character carried out in school and at the home. The program character has to touch the realm of three namely, cognitive, affective and psychomotor. The realm of cognitive achieved by having written messages and motivation. The realm of affective do with an example, and the realm of psychomotor do by the implementation of activity every day.

The first program that implemented was five prayer. This program was choosen because five prayer was very importent to built academic, diciplin, and harmony of student daily life. The student parent very apreciate to the character program. The head of school committee give apretiation to the program. He said "the program is very good. The people here very needed program like this to improve this school. I hope school make other character program". Some of student parent gave apretiation to the teacher. They said that his son become do five preyer althougt they did not make punishment.

The second program that implemented was keeping enviroment clean by not throwing rubbish everywhere. Rubbish was a communal problem. Without educate childern the negatif effect of throwing rubbish everywhere, environment could not be clean. Student must educate the dangerous of rubbish for health and environment. They must know that rubbish manage by reduce, reuse, and recycle. They also must know that rubbish could make become some beautiful handicraff. They must know that from the rubbish they could make money by selling organic fertilizer. The implementation of the application character program established as $95 \%$.

Supervision is conducted to assess whether the program character has been made or not. Supervision is conducted against the activity of students who do at school and at home. At school, supervition did by teacher. At home, supervition did by parent. An instrument of supervision students is in a guidebook of parenting. The implementation of the supervision program is established as $95 \%$.

Evaluation character education is summarized surveillance activities. The result of evaluation was taken to the programs established so that the program character performed can be better in the future. The implementation of the program evaluation is established as $80 \%$ [15].

\section{B. Discussion}

Thomas Lickona said that there are two steps to build a relation between school and parent. First monthly meeting. School invite presents to attended in monthly meeting at school. The Headmaster explain about the topic of the meeting is how to building student character. Character education is not only school duty but also parent. In addition, Comer and Heynes said that students will learn be better if their environment give support. The environment are parent, school, and community. [16].

The second is unity of parent class meeting. The teacher of class invite all parent in his class. The meeting must 
not take place at school but in one of parent home. The topic of meeting is the progress of student character. The character of student at school is explained by teacher and the character of student at home is explained by parent. In addition, Molloy said that the relationship can be expanded such as training, bazaar, and home visit [17].

Making programs, Thomas Lickona said that if the partnership between school and parent already exist, school and parent must arrange a character program. Why the program must create by school and parent to gather, Molloy said that the program that make by school and parent to gather can make both of them take more responsibility. So, the program will be success [18].

The program must be written in a book. The book is guidance for development character program. Teacher and parent arrangge the content of the book. The book is called parenting guidance book. According to Mark, parenting guidance book make significant role. The book helps parent to do what they must do [18].

Application of the program divides in two segment, applied at school and applied at home. Programs that applied at school such as habituation, learning, and giving example by teacher. Programs that applied at home such us giving motivation, learning, and habituation. According to Syarbini, character program that applied at school and at home have significant result to develop student character [19].

Program supervision is a way to make the program applied properly. When student at school, the supervision is done by teacher. When student at home, the supervision is done by parent. according to Grant, relationship must not obey responsibility and independency. So, supervision to the program must be done [20]. The result of supervision is used to make a new program in the next parent school meeting.

\section{CONCLUSION}

Model parenting produced consisting of five measures that is building partnerships, arrange a program, character, implementation of the program character, supervision program character, and evaluation program character. Pilot model shows that the percentage of implementation model produce good, programs established character produce the percentage good, the implementation of the program produces the percentage good, character monitoring programs produce the percentage good, and evaluation model produces the percentage good. Based on data analysis the implementation of model shows that the percentage of parenting produce is good. This shows that model parenting produced can be implemented well as to implement the conceptual character education in elementary school.

The result could be used as theoretical concept of a link between parenting by strengthening character education at the level primary school. The theoretical about between parenting and strengthening character education will enrich materials to lecture insight education management, and management of students. The result of this research expected to be practical guide character education in Glagahan 2 Perak
Jombang Elementary School, so that participation parents of students for education will rise and character the students in this school will also increase.

\section{REFERENCES}

[1] N. V. Roman, E. L. Davids, A. Moyo, L. Schilder, M. Lacante, and W. Lens, W. "Parenting styles and psychological needs influences on adolescent life goals and aspirations in a South African setting," Journal of Psychology in Africa, vol. 25, no.4, pp. 305-312, 2015.

[2] A. W. Dodd, "Educating for character: How our schools can teach respect and responsibility," by Thomas Lickona. New York: Bantam Books, 1991. NASSP Bulletin, vol. 76, no. 545, pp. 119-120, 1992.

[3] T. Lickona, "Character matters: How to help our children develop good judgement, integrity, and other essential virtues," New York: Simon \& Schuster, 2003.

[4] K. Prabandari and L. N. Yuliati. "The influence of social media use and parenting style on teenagers' academic motivation and academic achievement," Journal of Child Development Studies, vo. 1, no.1, pp. 39-53, 2016.

[5] A. Kordi and R. Baharudin. "Parenting attitude and style and its effect on children's school achievements," International Journal of Psychological Studies, vol. 2, no. 2, pp. 217, 2010.

[6] A. R. Kimaro and H. J. Machumu, "Impacts of parental involvement in school activities on academic achievement of primary school children," International Journal of Education and Research, vol. 3, no. 8, pp. 483-494, 2015.

[7] F. Bibi, A. G. Chaudhry, E. A. Awan, and B. Tariq, "Contribution of parenting style in life domain of children," IOSR Journal of humanities and social science (IOSR-JHSS), vol. 12, no. 2, pp. 91-95, 2013.

[8] L. Lekli and E. Kaloti, "Building parent-teacher partnerships as an effective means of fostering pupils' success," Academic Journal of Interdisciplinary Studies, vo. 4, no. 1, pp. 101, 2015.

[9] M. W. Berkowitz and M. C. Bier, "Character education: Parents as partners," Educational Leadership, vol. 63, no. 1, pp. 64-69, 2005.

[10] I. P. Asiabaka, "The need for effective facility management in schools in Nigeria," New York Science Journal, vol. 1, no. 2, pp. 10-21, 2008.

[11] U. Maryam, Strengthening the role of Parent Teachers Association in Education in Nigeria: Member CEF Steering Committee, Lagos, 2008.

[12] T. Lickona, "Competencies Needed by Secondary School Head Teachers and Implications on Pre-service Education," Unpublished Phd Thesis. Nairobi: Kenyatta University, 2001.

[13] R. Porpst, The High School: The Process and the Place, New York: Educational Facilities Laboratories, 1972.

[14] W. W. Rostow and W. W. Rostow, The stages of economic growth: A non-communist manifesto, Cambridge University Press, 1990.

[15] M. Ellis, L. Graeme and L. Geoff, "Parent-teacher interactions: Engaging with parents and carers." Australian Journal of Teacher Education, vol. 40, no. 5, pp. 9, 2015.

[16] P. E. Davis-Kean, "The influence of parent education and family income on child achievement: the indirect role of parental expectations and the home environment," Journal of Family Psychology, vol. 19, no. 2, pp. 294, 2005.

[17] J. P. Comer, and N. Haynes, The home school team, 1997.

[18] P. Molloy, G. Fleming, C. R. Rodriguez, N. Saavedra, B. Tucker, and D. L. Williams Jr. "Building home, school, community partnerships: The planning phase." Southwest Educational Development Laboratory: Austin, Texas, 1995.

[19] Syarbini, Inform educate action: Critical review of modernization theory, 2008.

[20] C. A. Grant, Community Participation in Education, Boston: Allyn \& Bacon, 1979. 